\title{
Interaction between hydrodynamics and seagrass canopy structure: Spatially explicit effects on ammonium uptake rates
}

\section{E. P. Morris ${ }^{1}$ and G. Peralta}

Department of Biology, Faculty of Marine and Environmental Sciences, University of Cádiz, 11510 Puerto Real (Cádiz), Spain

\section{F. G. Brun}

Department of Biology, Faculty of Marine and Environmental Sciences, University of Cádiz, 11510 Puerto Real (Cádiz), Spain; and the Department of Spatial Ecology, CEME-NIOO-KNAW, P.B. 140, 4400AC Yerseke, The Netherlands

\section{L. van Duren}

Department of Spatial Ecology, CEME-NIOO-KNAW, P.B. 140, 4400AC Yerseke, The Netherlands; and DELTARES, Rotterdamseweg 185, P.O. Box 177, 2600 MH Delft, The Netherlands

\section{T. J. Bouma}

Department of Spatial Ecology, CEME-NIOO-KNAW, P.B. 140, 4400AC Yerseke, The Netherlands

\section{J. L. Perez-Llorens}

Department of Biology, Faculty of Marine and Environmental Sciences, University of Cádiz, 11510 Puerto Real (Cádiz), Spain

\begin{abstract}
The hypotheses that (1) different seagrass morphologies may facilitate different nutrient uptake rates under similar hydrodynamic forcing and (2) this effect on nutrient uptake rates is spatially explicit, with the highest uptake rates at edges of patches, where currents and turbulence are highest, were examined under unidirectional flow conditions. Homogeneous patches ( $2 \mathrm{~m}$ long) of two seagrass species (Cymodocea nodosa and Zostera noltii) with contrasting shoot size and density were placed in a race track flume. ${ }^{15} \mathrm{NH}_{4}^{+}$uptake and hydrodynamic properties along a gradient from outside to inside the patch were measured at a range of current velocities $(0.05$ to $0.3 \mathrm{~m} \mathrm{~s}^{-1}$ ). For each velocity we also determined the height and bending of the canopy. Water velocity affected the ammonium uptake rate of both species. The almost double uptake rates of $C$. nodosa shoots, compared to those of $Z$. noltii, were mainly attributed to a twofold difference in the within-canopy water flow $\left(Q_{c}, \mathrm{~m}^{3} \mathrm{~s}^{-1}\right)$. Spatial patterns in canopy water flow were highly correlated with spatial patterns in $\mathrm{NH}_{4}^{+}$uptake, thereby explaining the $20 \%$ higher uptake rates at the leading edge of both canopies. The correlation between spatial patterns in canopy water flow and ammonium uptake rates underlines the role of canopy and patch configuration in determining the functioning of seagrass landscapes and their associated ecosystem services, such as nitrogen assimilation.
\end{abstract}

Seagrasses inhabit intertidal and subtidal areas throughout the world (Larkum et al. 2006), where they experience variable hydrodynamic forces that interact with their canopies (Koch et al. 2006). In general, velocities decrease

${ }^{1}$ Corresponding author (edward.morris@uca.es).

\section{Acknowledgments}

We thank Jos van Soelen, Bas Koutstaal, and Louie Haazen for invaluable technical assistance. In addition, we are grateful to Britta Gribsholt, Bart Veuger, Miguel Bernal, Juan Jose Vergara, and Alfredo Izquirdo for helpful discussion. In addition, we thank Josef D. Ackerman and the anonymous reviewers for comments that greatly improved the manuscript.

This work and the first author were supported by an EU Marie Curie host fellowship for transfer of knowledge, MTKD-CT2004-509254, and the Spanish national project EVAMARIA, CTM2005-00395/MAR. F.G.B. holds an EU Marie Curie individual fellowship, MEIF-CT-2005-515071.

This is publication 4251 of the Netherlands Institute of Ecology (NIOO-KNAW). within a seagrass canopy, whereas turbulence tends to increase within or at the top of the canopy, compared to turbulence in nonvegetated areas (Gambi et al. 1990; Ackerman and Okubo 1993; Koch and Gust 1999). Smallscale horizontal differences in hydrodynamics within seagrass canopies are also commonly observed, with canopy water flow generally decreasing downstream from the leading edge (Fonseca and Koehl 2006). These hydrodynamic interactions are often influenced by canopy deflection (Abdelrhman 2007), which depends upon characteristics such as shoot density (Gambi et al. 1990; Peterson et al. 2004; Bouma et al. 2005), shoot stiffness (Bouma et al. 2005), the occupied volume (Fonseca et al. 1982; Koch 2001), and patchiness (Folkard 2005).

Hydrodynamic conditions can affect the growth and morphometry of seagrass plants, either directly or indirectly (Fonseca and Kenworthy 1987; Schanz and Asmus 2003; Peralta et al. 2005). Indirect effects on growth may be understood by the influence of hydrodynamics on the mass 
transfer of resources to and from seagrass beds (Koch et al. 2006; Nishihara and Ackerman 2006). For example, seagrass photosynthesis (carbon uptake) responds to increasing current velocity (i.e., mass transfer limitation), up until a critical flow velocity $\left(<0.05 \mathrm{~m} \mathrm{~s}^{-1}\right)$, above which uptake is limited by plant kinetics (Koch 1994; Enriquez and Rodriguez-Roman 2006; Nishihara and Ackerman 2006). Nitrate assimilation also tends to be kinetically limited at relatively low critical current velocities $\left(<0.1 \mathrm{~m} \mathrm{~s}^{-1}\right)$ (Touchette and Burkholder 2000; Cornelisen and Thomas 2004), whereas ammonium assimilation appears to be mass transfer limited at velocities of $<0.3 \mathrm{~m} \mathrm{~s}^{-1}$ (Thomas et al. 2000; Cornelisen and Thomas 2002, 2004).

Depending on the abiotic conditions, foliar uptake can supply around $50 \%$ of the overall nitrogen $(\mathrm{N})$ requirement of Thalassia testudinum (Lee and Dunton 1999) and Thalassia hemprichii (Stapel et al. 1996), between $30 \%$ and $90 \%$ of the overall $\mathrm{N}$ requirement of Zostera marina (Iizumi et al. 1982; Short and McRoy 1984; Pedersen and Borum 1993), and in extreme cases, the complete $\mathrm{N}$ requirement of Phyllospadix torreyi (Terrados and Williams 1997). As foliar nitrogen uptake is generally much higher for $\mathrm{NH}_{4}^{+}$than for $\mathrm{NO}_{3}^{-}$(Touchette and Burkholder 2000), current velocity may play an important role in the supply of $\mathrm{N}$ to seagrasses.

Given the spatial patterns in canopy hydrodynamics and the effect of current velocity on nutrient uptake, we hypothesize that there may be spatial patterns in nutrient uptake within seagrass patches, with highest uptake at the leading edge. We also hypothesize that given the differences in shoot morphology and/or canopy structure, this spatial pattern may vary among species. To test our hypotheses, we compared the relationship between hydrodynamics and nutrient uptake in a spatially explicit way for two seagrass species that grow adjacently but that have a contrasting morphology. Zostera noltii (Hornem.) is a small, thinleaved seagrass that forms dense canopies in the intertidal zone, whereas Cymodocea nodosa (Ucria) Ascherson. is a relatively large plant with long wide leaves that forms more sparse canopies in the subtidal zone.

\section{Methods}

Plant material - Intact $Z$. noltii mats (i.e., plants within a sediment matrix) and $C$. nodosa plants were collected from Santibañez, Cádiz, in southwest Spain $\left(36^{\circ} 28^{\prime} 12.79^{\prime \prime} \mathrm{N}\right.$, $\left.06^{\circ} 15^{\prime} 7.07^{\prime \prime} \mathrm{W}\right)$ on 12 and 24 September 2005, respectively. The collection site is a sheltered tidal lagoon in which, apart from wind-induced waves, unidirectional flows dominate. Both species were transported to the Netherlands Institute for Ecology-Center for Estuarine and Marine Ecology (NIOO-CEME), southwest Netherlands, and placed into large holding tanks filled with aerated seawater from the adjacent Oosterschelde tidal lagoon (salinity 31; temperature $16^{\circ} \mathrm{C}$; $\left[\mathrm{NH}_{4}^{+}\right], 4.65 \mu \mathrm{mol} \mathrm{L}-1$; $\left.\left[\mathrm{NO}_{3}\right], 10.3 \mu \mathrm{mol} \mathrm{L}-1\right)$. Plants were kept under continuous illumination (200 $\mu$ mol quanta $\left.\mathrm{m}^{-2} \mathrm{~s}^{-1}\right)$ for $2 \mathrm{~d}$ using a combination of sodium halide and mercury lamps to recover from transport. The water within the holding tank was renewed every day. Three days before the flume experiments, the photoperiod was changed to $14 \mathrm{~h}$.

A number of shoots were selected haphazardly and placed in plastic plant pots $(0.06 \times 0.06 \mathrm{~m})$ filled with siliceous sediment $(0.25 \mu \mathrm{m})$. Leaves were wiped clean and pots were stored in the holding tank. Single species pots of $Z$. noltii contained around 30 shoots $\left(8,333\right.$ shoots $\left.\mathrm{m}^{-2}\right)$, while $C$. nodosa pots consisted of two shoots with a section of rhizome and roots $\left(555\right.$ shoots $\left.\mathrm{m}^{-2}\right)$. The remainder of the plants were used to make a $2-m$-long homogeneous bed within the flume tank test section; this was accomplished by carefully planting $Z$. noltii or $C$. nodosa in a bed of clean, level, siliceous sediment. The shoot densities (520 \pm 69 and 9,815 $\pm 1,271$ shoots $\mathrm{m}^{-2}$ for $C$. nodosa and $Z$. noltii, respectively), leaf area index (1.67 and 3.53), and aboveground biomass (54 and $78 \mathrm{~g}$ dry matter $\mathrm{m}^{-2}$ ) of the reconstructed beds represent the mean values observed at Santibañez over a season cycle (J. L. Perez-Llorens, unpubl.). We filled the whole width of the flume $(0.6 \mathrm{~m})$ with a canopy height of less than one half of the water depth so that our measurements would mimic the flow interaction typical for broad shallow seagrass beds (Fonseca and Koehl 2006). The plastic pots with prepotted seagrasses were inserted along the central axis of the patch at $x=0,0.1,0.2,0.5$, and $1 \mathrm{~m}$ (downstream of the leading edge). Care was taken to ensure that the edge of the pots was slightly below the sediment surface to prevent flow interaction and scouring.

Lamps were suspended above the flume tank to provide a homogeneous irradiance field throughout the test section. The photoperiod and photosynthetic photon flux density were constant during the experiment at $14 \mathrm{~h}$ and $280 \mu \mathrm{mol}$ quanta $\mathrm{m}^{-2} \mathrm{~s}^{-1}$ (measured using a cosine-corrected PAR sensor, LICOR, $10 \mathrm{~cm}$ above the sediment surface). Water temperature (T) and salinity (S) were maintained at a value of $16^{\circ} \mathrm{C} \pm 1{ }^{\circ} \mathrm{C}$ and $31 \pm 2$, respectively $\left(\mathrm{T}=17^{\circ} \mathrm{C} \pm 3^{\circ} \mathrm{C}\right.$ and $\mathrm{S}=34 \pm 2$ at the field site when the plants were collected).

Hydrodynamic measurements in the flume tank-The effect of $Z$. noltii and $C$. nodosa vegetation on hydrodynamic variables was studied in a unidirectional flow 'race track' flume tank with a water column height of $0.4 \mathrm{~m}$ and a volume of $10 \mathrm{~m}^{3}$ (for details, see fig. 1 in Bouma et al. 2005 or www. nioo.nl/science/facilities/flume/flume.htm). Measurements were performed at free stream velocities $(\bar{u}$ at $z=0.3 \mathrm{~m})$ of approximately $0.05,0.1,0.15,0.2$, and $0.3 \mathrm{~m} \mathrm{~s}^{-1}$, obtained by regulating the rotation frequency of the flume paddle. The velocity components $(u, v$, and $w$ in the downstream, crossstream, and vertical directions, respectively) were measured at $25 \mathrm{~Hz}$ with an acoustic Doppler velocimeter (ADV, Nortek field version). Vertical hydrodynamic profiles were measured in the downstream flow direction $(x)$ from outside to inside of the patch using a grid design consisting of 600 individual measuring points. The grid was made up of six $x$ locations, at $x=-0.1 \mathrm{~m}$, over bare sand, and at $x=0,0.1$, $0.2,0.5$, and $1 \mathrm{~m}$, within the patch; five cross-stream $(y)$ locations, spaced $0.03 \mathrm{~m}$ apart; and 20 vertical $z$-locations, extending from near the bed to $>0.3 \mathrm{~m}$.

Time-averaged velocity components $(\bar{u}, \bar{v}$, and $\bar{w})$ and their fluctuations $\left(u^{\prime}, v^{\prime}\right.$, and $\left.w^{\prime}\right)$ were calculated by 

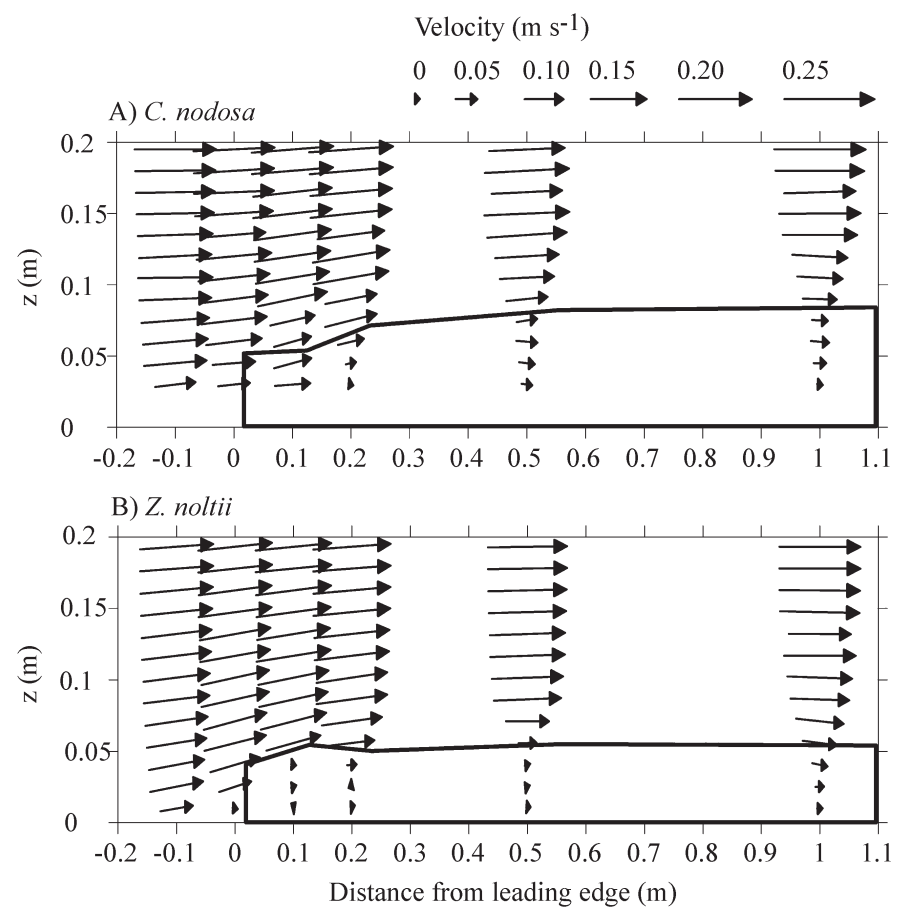

Fig. 1. Vector plots of horizontal $(\bar{u})$ and vertical $(\bar{w})$ mean water velocity $\left(\mathrm{m} \mathrm{s}^{-1}\right)$ over reconstructed (A) C. nodosa and (B) Z. noltii patches $(2 \times 0.06 \mathrm{~m})$ subjected to fast flow (velocity treatment $0.2 \mathrm{~m} \mathrm{~s}^{-1}$ ). Canopy height is signified by the black outline.

averaging the temporal measurements $(5 \mathrm{~s}$ at $25 \mathrm{~Hz}, n=$ 125) at each sampling point. From these, Reynolds stress $\left(\tau_{x z},-\overline{u^{\prime} w^{\prime}}, \mathrm{cm}^{2} \mathrm{~s}^{-2}\right)$ and turbulent kinetic energy (TKE, $0.5\left[u^{\prime 2}+v^{\prime 2}+w^{\prime 2}\right], \mathrm{mm}^{2} \mathrm{~s}^{-2}$ ) were calculated according to the method of Jonsson et al. (2006). To minimize disturbance by structures within the ADV probe measuring volume (i.e., compression of the canopy as the probe moves toward the bed), which can cause unreliable data, the robotic probe started at its lowest position on each vertical profile. Low correlations (supplied in the ADV output file) indicate unreliable data. Obvious outliers and data points with correlations of $<70 \%$ were filtered, so that measurements within the canopy are usually based on a slightly reduced number of reliable data points. Generally, time series of data were almost complete and always contained $>90 \%$ of the data.

In order to reduce variability in hydrodynamic parameters related to cross-stream variation in the canopy, vertical profiles of $\bar{u}, \tau_{x z}$, and TKE were constructed by spatially averaging the five $y$-locations for each $x, z$ coordinate. These double-averaged (i.e., in time and then space) vertical profiles were used to estimate $\tau_{x z}$ at the top of the canopy and TKE within the canopy at each $x$ location. Finally, the double-averaged velocity gradients were used to calculate the volumetric flow rate of water through the canopy $\left(Q_{c}, \mathrm{~m}^{3} \mathrm{~s}^{-1}\right)$ :

$$
Q_{c}=\sum_{0}^{Z_{c}} Q_{i} \quad \text { and } \quad Q_{i}=y\left(z_{i}-z_{i-1}\right) \bar{u}_{z_{i}}
$$

where $Z_{c}$ is the height of the canopy, $Q_{i}$ the volumetric flow rate of water through the layer $\left(z_{i}-z_{i-1}\right), y$ the width of the flume tank $(0.6 \mathrm{~m})$, and $\bar{u}_{z_{i}}$ the double-averaged $u$ component of the velocity at depth $z_{i}$.

Meadow height during the flume experiments - The height and shape of the canopy at each of the $x$ positions was traced onto transparency film and digitized to enable analysis of the canopy height $\left(z_{c}\right)$ and bending angle of five individual plants. Plant morphological characteristics were also examined (mean \pm standard deviation $[\mathrm{SD}], n=30$ ); leaf length was $0.18 \pm 0.09$ and $0.08 \pm 0.03 \mathrm{~m}$; width $3.8 \pm$ $0.4 \times 10^{-3}$ and $1.1 \pm 0.2 \times 10^{-3} \mathrm{~m}$; thickness $191 \pm 54 \times$ $10^{-6}$ and $152 \pm 55 \times 10^{-6} \mathrm{~m}$; and the number of leaves per shoot $3.5 \pm 1.1$ and $4 \pm 0.8$ for $C$. nodosa and $Z$. noltii shoots, respectively. $C$. nodosa shoots also had a sheath at the base of their leaves, which had a mean length, width, and thickness of $0.06 \pm 0.01,4.5 \pm 0.4 \times 10^{-3}$, and 1,115 $\pm 195 \times 10^{-6} \mathrm{~m}$, respectively. Two canopy regions were defined: (1) 'top of the canopy,' defined as canopy height $\left(z_{c}\right) \pm 10 \%$, and (2) 'within the canopy,' defined as $z_{c}+10 \%$ to $z=0$.

Ammonium uptake experiment in the flume tank-Uptake rates were determined twice at the five free stream water velocities for each species (on two consecutive days). Five new pots were taken from the holding tank and placed within the 'structural' bed for every new velocity treatment. The water within the flume was replaced each day. While we recognize that the velocity treatments are not truly independent, refilling the flume before each velocity treatment was not feasible. Therefore, velocity treatments were conducted in a semirandom order (i.e., different on each replicate day), and corrections were made for the decrease in $\left[\mathrm{NH}_{4}^{+}\right]$within the flume tank over the 8-h experimental period (details below).

Velocity treatments began at 10:30 h (after $2 \mathrm{~h}$ of irradiance). A spike of ${ }^{15} \mathrm{NH}_{4}^{+}$(as $9.7 \mathrm{mmol} \mathrm{L}-1$ of 99.16 atom\% ${ }^{15} \mathrm{NH}_{4} \mathrm{Cl}$ ) was added to the flume to obtain an initial water $\left[\mathrm{NH}_{4}^{+}\right]$of $\sim 5 \mu \mathrm{mol} \mathrm{L}{ }^{-1}$. The spike was added slowly (over $\sim 5 \mathrm{~min}$ ) near the paddles to ensure mixing. Ambient water samples $(n=5)$ were collected prior to adding the spike to measure the background nutrient levels and throughout the day to assess any changes in nutrient concentrations. On each replicate day, incubations of five pots were also carried out in a 20-liter container (with the same irradiance conditions and incubation time) using labeled water from the flume in order to assess the $\mathrm{NH}_{4}^{+}$ uptake rate of plants under 'static' conditions (i.e., $0 \mathrm{~m} \mathrm{~s}^{-1}$ velocity treatment).

Deriving ammonium uptake rates-The pots were removed from the flume after each velocity treatment, and the plants were extracted and rinsed (with saltwater and then freshwater) to remove any excess label or sediment. Tissues were separated into aboveground (shoots and sheath) and belowground (rhizomes and roots) biomass and were immediately frozen at $-80^{\circ} \mathrm{C}$. After 1 week the biomass was freeze-dried, ground to a fine powder, and analyzed in an elemental analyzer coupled with an isotope ratio mass spectrometer (Europa Hydra IRMS coupled to a 

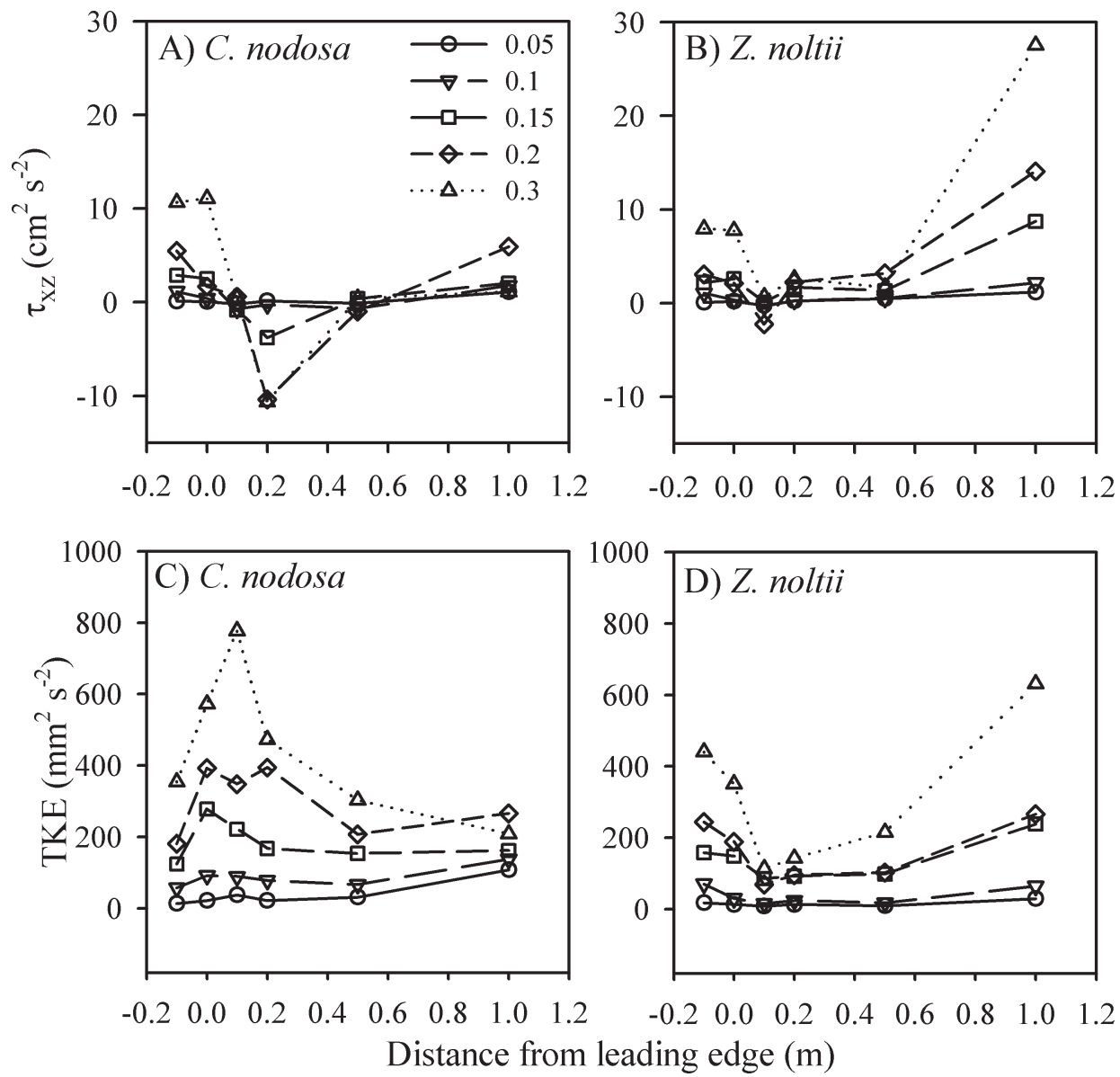

Fig. 2. Reynolds stress $\left(\tau_{x z}, \mathrm{~cm}^{2} \mathrm{~s}^{-2}\right)$ at the top of the canopy and turbulent kinetic energy (TKE, $\mathrm{mm}^{2} \mathrm{~s}^{-2}$ ) within the canopy at increasing horizontal distances from the leading edge of reconstructed (A, C) C. nodosa and (B, D) Z. noltii patches during velocity treatments (0.05$0.3 \mathrm{~m} \mathrm{~s}^{-1}$, represented by the different symbols).

Carlo Erba NC250) for determination of nitrogen content $(\% \mathrm{~N})$ and atom\% ${ }^{15 \mathrm{~N}}$. Specific $\mathrm{NH}_{4}^{+}$uptake rates $(V)$ were calculated according to Cornelisen and Thomas (2004):

$$
V=\left(d a_{s} / d t\right) /\left(a_{w}-a_{s}\right)
$$

where $a_{s}$ is the atom $\%{ }^{15} \mathrm{~N}$ in the component's tissue, $a_{w}$ is the atom $\%{ }^{15} \mathrm{~N}$ of the enriched substrate, and $t$ is time of incubation (h). The atom\% ${ }^{15} \mathrm{~N}$ of the enriched water $\left(a_{w}\right)$ was calculated from the amount of $99.1 \%{ }^{15} \mathrm{NH}_{4}^{+}$added to the flume and the initial water column $\left[\mathrm{NH}_{4}^{+}\right]$(assumed to reflect ${ }^{15} \mathrm{~N}$ of atmospheric $\mathrm{N} \sim 0.37$ atom\% ${ }^{15} \mathrm{~N}$ ). The numerator $\left(d a_{s} / d t\right)$ was calculated as the difference in atom $\%$ ${ }^{15} \mathrm{~N}$ between ambient samples and the samples collected at the end of each velocity treatment divided by the duration of the experiment $(1.5 \mathrm{~h})$. No correction was made for dilution of the ${ }^{15} \mathrm{~N}$ source pool; the large volume of the flume and high atom $\%{ }^{15} \mathrm{~N}$ of the spike minimized dilution effects. Specific uptake rates $(V)$ were normalized to the $\mathrm{N}$ content $(\% \mathrm{~N})$ of the tissue to yield an uptake rate in units $\mathrm{g} \mathrm{N}$ assimilated (g dry matter) $)^{-1} \mathrm{~h}^{-1}$. The $\mathrm{N}$ content (mean \pm $\mathrm{SD}, n=50$ ) of $C$. nodosa and $Z$. noltii aboveground tissues was $2.58 \% \pm 0.20 \%$ and $2.37 \% \pm 0.20 \%$, respectively.
To compensate for changes in $\left[\mathrm{NH}_{4}^{+}\right]$over time (assumed to be first-order changes), uptake rates were multiplied by a correction term $(\alpha)$ (Cornelisen and Thomas 2006), thus:

$$
\alpha=k t /\left(1-e^{-k t}\right)
$$

Values of $\alpha$ ranged from 0.4 to 3 in each experiment. Corrected uptake rates represent those for the watercolumn $\left[\mathrm{NH}_{4}^{+}\right]$at the start of each experimental day $\left(\sim 5 \mu \mathrm{mol} \mathrm{L}{ }^{-1}\right)$. Finally, uptake rates measured at each $x$ location were multiplied by the aboveground biomass of each patch and integrated to yield an estimate of areal uptake (mg N [m sediment surface $]^{-2} \mathrm{~h}^{-1}$ ) for each species. Only the biomass of leaves ( $40 \mathrm{~g} \mathrm{DM} \mathrm{m}^{-2}$ ) was considered in areal uptake calculations for $C$. nodosa patches (i.e., sheath biomass was excluded).

Statistics - Nested analysis of variance (ANOVA) was used to examine statistical differences between the $\mathrm{NH}_{4}^{+}$ uptake rates of each species incubated in static conditions (with pots nested within replicate days). ANOVA analysis was not applied to the data collected during velocity treatments as a result of the limited amount of replication 

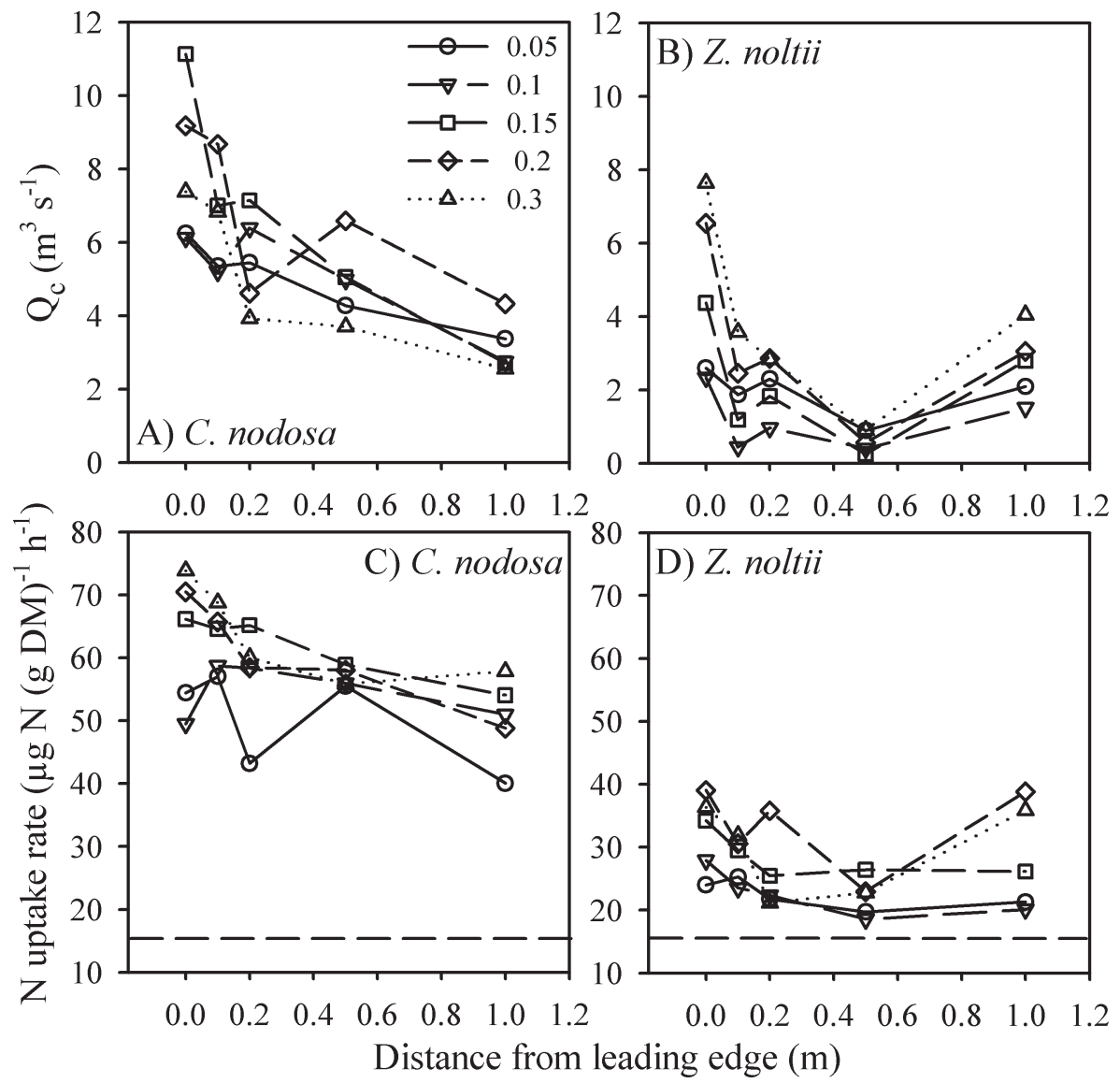

Fig. 3. Canopy water flow $\left(Q_{c}, \mathrm{~m}^{3} \mathrm{~s}^{-1}\right)$ and ammonium uptake rate of aboveground tissues $\left(\mu \mathrm{g} \mathrm{N}\left[\mathrm{g} \mathrm{DM}^{-1} \mathrm{~h}^{-1}\right)\right.$ at increasing horizontal distances from the leading edge of reconstructed (A, C) C. nodosa and (B, D) Z. noltii patches during velocity treatments $\left(0.05-0.3 \mathrm{~m} \mathrm{~s}^{-1}\right.$, represented by the different symbols). The dashed straight line represents the ammonium uptake rates of each species in 'static conditions.'

and the noninterdependence among treatments. However, significant correlations between uptake rates and hydrodynamic and canopy parameters were assessed using Pearson's correlation coefficient (which is statistically less restrictive, but also less powerful). An alpha value of 0.05 was considered significant. Statistical procedures were carried out in Statistica 7.0 (StatSoft).

\section{Results}

Hydrodynamics-Mean water velocities $(\bar{u})$ averaged over the vertical water column and canopy $(\bar{U})$ were comparable for $C$. nodosa and $Z$. noltii. That is, $\bar{U}$ ranged from a minimum of $0.05 \mathrm{~m} \mathrm{~s}^{-1}$ to a maximum of $0.31 \mathrm{~m} \mathrm{~s}^{-1}$ in $C$. nodosa and from a minimum of $0.04 \mathrm{~m} \mathrm{~s}^{-1}$ to a maximum of $0.28 \mathrm{~m} \mathrm{~s}^{-1}$ in the $Z$. noltii experiments, with the minor differences due to slight differences in the external forcing. The canopy was deflected with increasing velocity treatment in both species. The initial height of the C. nodosa and $Z$. noltii canopies was $0.17 \pm 0.02 \mathrm{~m}$ and $0.09 \pm 0.01 \mathrm{~m}$, respectively. The bending of plants increased with increasing velocity treatments until the canopy height of both species was about $0.04 \mathrm{~m}$ at $0.3 \mathrm{~m} \mathrm{~s}^{-1}$.
Generally, velocity vector plots of $\bar{u}$ and $\bar{w}$ showed similar patterns at all the velocity treatments. Flow was deflected upwards and accelerated over the leading edge of the patch, resulting in low water velocities within the canopy and higher velocities above (example shown in Fig. 1). The magnitude of flow attenuation within the dense $Z$. noltii canopy appeared to be stronger than in the sparse C. nodosa canopy, where substantial flow penetration was observed. Indications of downward flow into the canopy were observed at $1 \mathrm{~m}$ from the leading edge, indicating the presence of a downstream wake region. This effect was much stronger in the $Z$. noltii vegetation, with highly positive values of Reynolds stress $\left(\tau_{x z}\right)$ observed at $1 \mathrm{~m}$ from the leading edge (Fig. 2). In contrast, negative $\tau_{x z}$ was observed toward the leading edge of the C. nodosa vegetation. TKE within the canopy, a measure of turbulent activity that is related to flow velocity, was comparable between the two species. However, the position of TKE maxima differed notably. For C. nodosa, maximum TKE was observed at $0.2 \mathrm{~m}$, while for $Z$. noltii, maximum values were observed $1 \mathrm{~m}$ downstream of the leading edge.

Using the measured canopy heights and velocity profiles at each position, the water flow passing through the canopy 


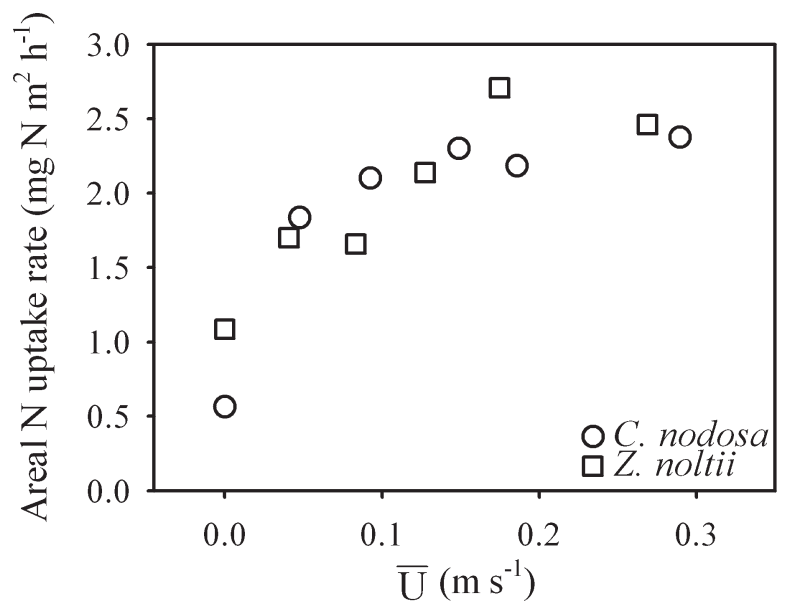

Fig. 4. Areal ammonium uptake rate $(\mu \mathrm{g} \mathrm{N}[\mathrm{m}$ sediment $]^{-2} \mathrm{~h}^{-1}$ ) of reconstructed $C$. nodosa and $Z$. noltii patches during increasing velocity treatments.

$\left(Q_{c}\right)$ was calculated for every experimental case (Fig. 3). $Q_{c}$ of C. nodosa (range, $2.6-11 \mathrm{~m}^{3} \mathrm{~s}^{-1}$ ) tended to be higher than that of $Z$. noltii (range, $0.24-7.6 \mathrm{~m}^{3} \mathrm{~s}^{-1}$ ). Generally, maximum $Q_{c}$ was observed close to the leading edge of the $C$. nodosa patch; water flow then decreased, reaching a minimum $1 \mathrm{~m}$ downstream. For $Z$. noltii, maximum $Q_{c}$ was also observed close to the leading edge. However, minimum $Q_{c}$ values were observed at $0.5 \mathrm{~m}$, with a relative enhancement observed at $1 \mathrm{~m}$. Flow attenuation tended to be higher in the $Z$. noltii canopy (11-95\%) than in the $C$. nodosa canopy (5-65\%).

Ammonium uptake rates-Uptakes rates of C. nodosa ranged from 15.0 in static conditions to $66.6 \mu \mathrm{g} \mathrm{N}$ $(\mathrm{g} \mathrm{DM})^{-1} \mathrm{~h}^{-1}$ at $0.2 \mathrm{~m} \mathrm{~s}^{-1}$, and for $Z$. noltii from 15.2 in static conditions to $34.1 \mu \mathrm{g} \mathrm{N}$ (g DM) $)^{-1} \mathrm{~h}^{-1}$ at $0.2 \mathrm{~m} \mathrm{~s}^{-1}$ (Fig. 3). Uptake of shoots incubated in static conditions was not significantly different between the two species (nested ANOVA, $F_{1,20}=0.56, p=0.46$ ), whereas in unidirectional flow, the maximum uptake of $C$. nodosa was approximately double that of $Z$. noltii. Enhanced uptake was observed at the leading edge of the patches of both species (Fig. 3). Uptake of C. nodosa shoots generally declined downstream of the leading edge at all velocities. In contrast, enhanced $Z$. noltii uptake was also observed $1 \mathrm{~m}$ from the leading edge at the highest velocities $(0.2$ and $0.3 \mathrm{~m} \mathrm{~s}^{-1}$ ). Thus, the results show that $\mathrm{NH}_{4}^{+}$uptake exhibited species-specific, spatially explicit patterns. Nevertheless, when areal uptake rates $(\mathrm{mg} \mathrm{N}$ [m sediment] ${ }^{-2} \mathrm{~h}^{-1}$ ) were calculated for each species, uptake was similar between the two species (Fig. 4), because of the almost double aboveground biomass of the $Z$. noltii patch. This indicates that while the efficiency of $\mathrm{N}$ assimilation (i.e., $\mathrm{g} \mathrm{N}$ [g DM leaf] ${ }^{-1} \mathrm{~h}^{-1}$ ) imposed by the species-specific canopy structure was different at similar external forcing, the total potential areal $\mathrm{N}$ assimilation of both species was almost equal.

Correlations between canopy properties, hydrodynamics, and ammonium uptake - The existence of a spatial pattern for both nutrient uptake and several hydrodynamic parameters (Figs. 1-3) raises the question of how these are related. When both canopies were considered together, as expected, TKE was significantly correlated with $\bar{U}, \tau_{x z}$, and $Q_{c}$ (Table 1). Canopy properties (height and bending angle) were associated with $\bar{U}$ and, to a lesser extent, TKE, and $Q_{c}$. However, because of species-specific differences in height, density, and canopy compression, $Q_{c}$ was not significantly correlated with $\bar{U}$.

Nearly all canopy and hydrodynamic parameters were significantly correlated with $\mathrm{NH}_{4}^{+}$uptake when each species was examined individually (Table 2; Fig. 5), reinforcing the observed high autocorrelation among hydrodynamic parameters. However, for both species the correlation coefficient between $Q_{c}$ and uptake was one of the highest, at 0.64 and 0.74 for C. nodosa and Z. noltii, respectively. Reynolds stress was not correlated with uptake for C. nodosa, but was important for Z. noltii shoots. The latter indicates that turbulent mixing had a role in determining uptake rates in the denser vegetation.

When the combined data sets of both seagrass species were considered, all variables except canopy height and $\tau_{x z}$ were significantly correlated with ammonium uptake (Table 2; Fig. 5). However, uptake was substantially more strongly correlated with $Q_{c}$ than with any other variable (Table 2; Fig. 5). Examination of the scatter plots indicated that while canopy and hydrodynamic variables correlated well with uptake rates for each species individually,

Table 1. Pearson's correlation of canopy (canopy height, $\mathrm{m}$, and bending angle, ${ }^{\circ}$ ) and the hydrodynamic parameters mean water column and canopy velocity, $\bar{U}\left(\mathrm{~m} \mathrm{~s}^{-1}\right)$; Reynolds stress, $\tau_{x z}\left(\mathrm{~cm}^{2} \mathrm{~s}^{-2}\right)$; turbulent kinetic energy, TKE $\left(\mathrm{mm}^{2} \mathrm{~s}^{-2}\right)$; and canopy water flow, $Q_{c}\left(\mathrm{~m}^{3} \mathrm{~s}^{-1}\right)$, of both seagrass species considered together ( $C$. nodosa and $Z$. noltii). Correlations in bold are significant at $p<0.05, n=50$.

\begin{tabular}{lrrrrr}
\hline \hline & Height & Angle & $\bar{U}$ & $\tau_{x z}$ & TKE \\
\hline Angle & $\mathbf{0 . 6 2}$ & 1.00 & & & \\
$\bar{U}$ & $-\mathbf{0 . 7 1}$ & $-\mathbf{0 . 8 0}$ & 1.00 & & \\
$\tau_{x z}$ & 0.22 & 0.10 & -0.25 & 1.00 & \\
TKE & $-\mathbf{0 . 4 6}$ & $-\mathbf{0 . 6 2}$ & $\mathbf{0 . 7 8}$ & $-\mathbf{0 . 3 4}$ & 1.00 \\
$Q_{c}$ & 0.02 & $-\mathbf{0 . 5 3}$ & 0.25 & -0.02 & $\mathbf{0 . 4 7}$ \\
\hline
\end{tabular}


Table 2. Pearson's correlation of canopy (canopy height, m, and bending angle, ${ }^{\circ}$ ) and the hydrodynamic parameters mean water column and canopy velocity, $\bar{U}\left(\mathrm{~m} \mathrm{~s}^{-1}\right)$; Reynolds stress, $\tau_{x z}$ $\left(\mathrm{cm}^{2} \mathrm{~s}^{-2}\right)$; turbulent kinetic energy, TKE $\left(\mathrm{mm}^{2} \mathrm{~s}^{-2}\right)$; and canopy water flow, $Q_{c}\left(\mathrm{~m}^{3} \mathrm{~s}^{-1}\right)$ with $\mathrm{NH}_{4}^{+}$uptake rates $\left(\mu \mathrm{g} \mathrm{N}[\mathrm{g} \mathrm{DM}]^{-1}\right.$ $\mathrm{h}^{-1}$ ), of $C$. nodosa, Z. noltii, and both seagrass species considered together. Incubations in static hydrodynamic conditions were not used in the analysis. Correlations in bold are significant at $p<0.05$.

\begin{tabular}{lccc}
\hline \hline & C. nodosa $(n=25)$ & Z. noltii $(n=25)$ & All $(n=50)$ \\
\hline Height & $-\mathbf{0 . 7 3}$ & $-\mathbf{0 . 5 7}$ & 0.13 \\
Angle & $-\mathbf{0 . 6 4}$ & $-\mathbf{0 . 7 0}$ & $-\mathbf{0 . 5 2}$ \\
$\bar{U}$ & $\mathbf{0 . 5 9}$ & $\mathbf{0 . 5 2}$ & $\mathbf{0 . 3 1}$ \\
$\tau_{x z}$ & -0.09 & $-\mathbf{0 . 4 8}$ & 0.15 \\
TKE & $\mathbf{0 . 6 4}$ & $\mathbf{0 . 6 0}$ & $\mathbf{0 . 5 2}$ \\
$Q_{c}$ & $\mathbf{0 . 6 4}$ & $\mathbf{0 . 7 4}$ & $\mathbf{0 . 8 0}$ \\
\hline
\end{tabular}

$Q_{c}$ seemed to be the only variable that could explain variation in the uptake independently of the species studied.

\section{Discussion}

The present results demonstrate the effect of both increasing unidirectional current velocity and spatial position on ammonium uptake rates of shoots from two seagrass species with different canopies (i.e., shoot density and leaf length) (Fig. 3). In addition to being consistent with the results of previous studies revealing the physically limited nature of $\mathrm{NH}_{4}^{+}$uptake in seagrass communities (Thomas et al. 2000; Cornelisen and Thomas 2002, 2006), our data support the hypothesis that there are spatial patterns in $\mathrm{NH}_{4}^{+}$uptake within seagrass patches. Of the hydrodynamic variables examined, canopy flow $\left(Q_{c}\right)$ was the most predictive variable in determining both the effect of position and velocity treatment, simultaneously explaining variation in the uptake of both species (Fig. 5). The weak effect of velocity treatments on $Q_{c}$ emphasizes the high level of relevance of canopy compression (Thomas et al. 2000; Abdelrhman 2007), indicating that flexibility may be an important trait that can simultaneously determine both the local phylloclimate and the ecosystem engineering capacity of submerged macrophytes (Bouma et al. 2005; Brun et al. 2006; Peralta et al. 2006).

Turbulent transport and mixing of the rapid overflow into the canopy had a role in determining uptake in the dense $Z$. noltii bed (Table 2). The positive values of $\tau_{x z}$ and slightly enhanced $Q_{c}$ observed at $1 \mathrm{~m}$ (Figs. 2,3) indicated that the 'wake' resulting from the flow separation initiated at the leading edge (Fig. 1) was responsible for enhanced uptake in Z. noltii. However, it should be noted that this hydrodynamic structure may (in part) have been a consequence of the restricted flow within the flume tank and thus may not manifest in the field. Nevertheless, these preliminary observations strongly indicate that the importance of turbulent mixing in determining $\mathrm{N}$ uptake is canopy architecture specific, supporting the second hypothesis that spatial patterns in $\mathrm{N}$ uptake are also dependent on the canopy properties of different species (Peterson et al. 2004).

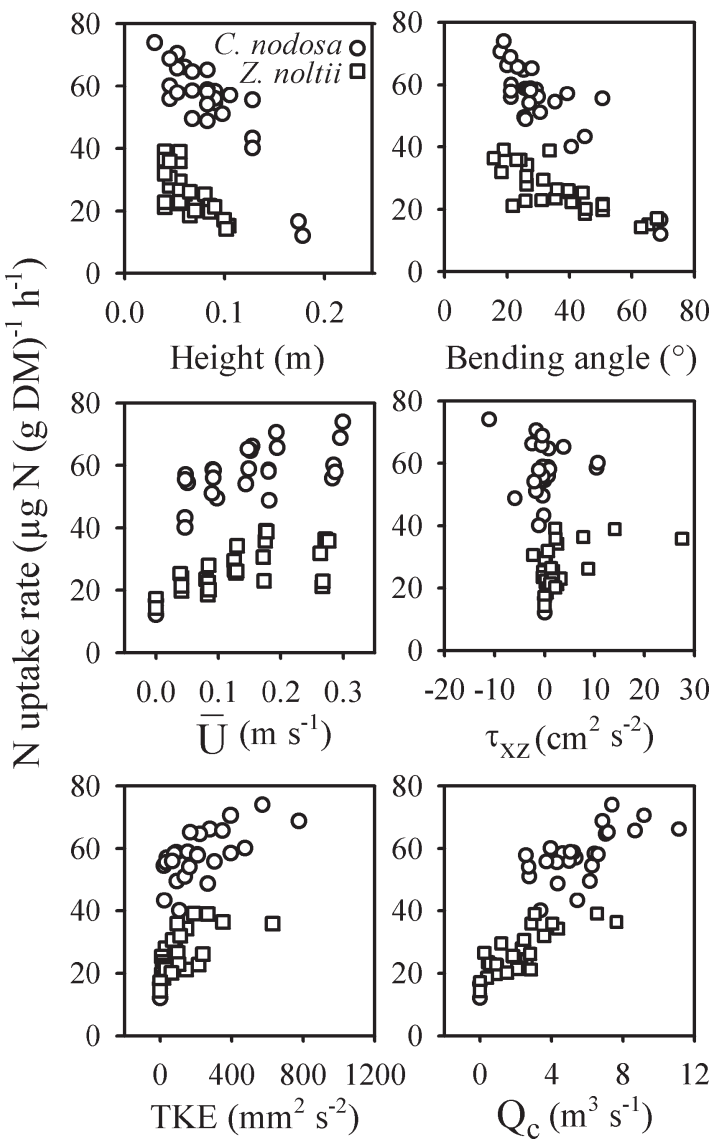

Fig. 5. Scatter plots of ammonium uptake rate of aboveground tissues $\left(\mu \mathrm{g} \mathrm{N}[\mathrm{g} \mathrm{DM}]^{-1} \mathrm{~h}^{-1}\right)$ against height and bending angle of the canopy, vertically averaged water velocity $(\bar{U})$, Reynolds stress $\left(\tau_{x z}\right)$ at the top of the canopy, canopy turbulent kinetic energy (TKE), and water flow $\left(Q_{c}\right)$ measured at increasing horizontal distances from the leading edge of reconstructed $C$. nodosa and $Z$. noltii patches during a range of unidirectional velocity treatments.

Rates of ammonium uptake (range, 15-66.6 $\mu \mathrm{g} \mathrm{N}$ $[\mathrm{g} \mathrm{DM}]^{-1} \mathrm{~h}^{-1}$ ) were comparable to those previously reported for seagrasses (see Touchette and Burkholder 2000; range, 5-270 $\mu \mathrm{g} \mathrm{N}$ [g DM] $]^{-1} \mathrm{~h}^{-1}$ ). In general, uptake rates of $C$. nodosa were approximately double those of $Z$. noltii (Fig. 3). However, the uptake affinity (i.e., physiological assimilation efficiency in static conditions) of each species was equal. This indicates that differences in uptake rates were due to (1) the canopy properties and (2) how these properties interacted with the unidirectional flow. The almost double $Q_{c}$ value of $C$. nodosa indicates that its canopy structure was more efficient at assimilating ammonium from the water column (i.e., allowed a higher supply of $\mathrm{NH}_{4}^{+}$to the leaves). Interestingly, as a result of the higher biomass of the $Z$. noltii canopy, areal ammonium uptake rates $(\mathrm{g} \mathrm{N} \text { [m sediment }]^{-2} \mathrm{~h}^{-1}$ ) of both species were actually relatively similar (Fig. 4).

Whether these effects persist in 'oscillatory' turbulent conditions, such as under the influence of waves, which often occur in 'real-world' situations, is unknown. Thomas and Cornelisen (2003) demonstrated that increased turbu- 
lence combined with the wave-induced movement of shoots acting to 'open up the canopy' can lead to an enhancement of $\mathrm{NH}_{4}^{+}$uptake. How these processes interact with spatial gradients caused by unidirectional flow is still unclear and will require further investigation. Over time, 'edge effects' in hydrodynamics and uptake (Guest et al. 2004) may affect shoot development and growth (Jensen and Bell 2001; Peralta et al. 2006), possibly providing a mechanism that can help to explain the emergent properties of seagrass landscapes (Sintes et al. 2005; Brun et al. 2006). Furthermore, the results of this study indicate that (1) changes in canopy properties and plant morphology (intra- and interspecies) will affect the supply of ammonium to the benthos; and (2) as a result of 'edge effects,' fragmented or patterned rather than 'homogeneous' landscapes maybe more efficient (when considering the whole landscape) at obtaining ammonium from the water column.

\section{References}

Abdelrhman, M. A. 2007. Modelling coupling between eelgrass Zostera marina and water flow. Mar. Ecol. Prog. Ser. 338: 81-96.

Ackerman, J. D., And A. Okubo. 1993. Reduced mixing in a marine macrophyte canopy. Funct. Ecol. 7: 305-309.

Bouma, T. J., M. B. De Vries, E. Low, G. Peralta, C. Tanczos, J. Van De Koppel, and P. M. J. Herman. 2005. Trade-offs related to ecosystem engineering: A case study on stiffness of emerging macrophytes. Ecology 86: 2187-2199.

Brun, F. G., J. J. Vergara, G. Peralta, M. P. Garcia-Sanchez, I. Hernandez, and J. L. Perez-Llorens. 2006. Clonal building, simple growth rules and phylloclimate as key steps to develop functional-structural seagrass models. Mar. Ecol. Prog. Ser. 323: 133-148.

Cornelisen, C. D., And F. I. M. Thomas. 2002. Ammonium uptake by seagrass epiphytes: Isolation of the effects of water velocity using an isotope label. Limnol. Oceanogr. 47: $1223-1229$.

2004. Ammonium and nitrate uptake by leaves of the seagrass Thalassia testudinum: Impact of hydrodynamic regime and epiphyte cover on uptake rates. J. Mar. Syst. 49: 177-194.

- AND —. 2006. Water flow enhances ammonium and nitrate uptake in a seagrass community. Mar. Ecol. Prog. Ser. 312: $1-13$.

Enriquez, S., And A. Rodriguez-Roman. 2006. Effect of water flow on the photosynthesis of three marine macrophytes from a fringing-reef lagoon. Mar. Ecol. Prog. Ser. 323: 119-132.

Folkard, A. M. 2005. Hydrodynamics of model Posidonia oceanica patches in shallow water. Limnol. Oceanogr. 50: 1592-1600.

Fonseca, M. S., J. S. Fisher, J. C. Zieman, and G. W. Thayer. 1982. Influence of the seagrass Zostera marina L. on current flow. Estuar. Coast. Shelf Sci. 15: 351-364.

- AND W. J. Kenworthy. 1987. Effects of current on photosynthesis and distribution of seagrasses. Aquat. Bot. 27: $59-78$.

, And M. A. R. Koenl. 2006. Flow in seagrass canopies: The influence of patch width. Estuar. Coast. Shelf Sci. 67: $1-9$.

Gambi, M. C., A. R. M. Nowell, and P. A. Jumars. 1990. Flume observations on flow dynamics in Zostera marina (eelgrass) beds. Mar. Ecol. Prog. Ser. 61: 159-169.
Guest, M. A., R. M. Connolly, and N. R. Loneragan. 2004 Within and among-site variability in $\delta^{13} \mathrm{C}$ and $\delta^{15} \mathrm{~N}$ for three estuarine producers, Sporobolus virginicus, Zostera capricorni, and epiphytes of $Z$. capricorni. Aquat. Bot. 79: 87-94.

Iizumi, H., A. Hattori, and C. P. McRoy. 1982. Ammonium regeneration and assimilation in eelgrass (Zostera marina) beds. Mar. Biol. 66: 59-65.

Jensen, S., AND S. Bell. 2001. Seagrass growth and patch dynamics: Cross-scale morphological plasticity. Plant Ecol. 155: 201-217.

Jonsson, P. R., AND OTHERs. 2006. Making water flow: A comparison of the hydrodynamic characteristics of 12 different benthic biological flumes. Aquat. Ecol. 40: 409-438.

$\mathrm{Koch}$, E. W. 1994. Hydrodynamics, diffusion-boundary layers and photosynthesis of the seagrasses Thalassia testudinum and Cymodocea nodosa. Mar. Biol. 118: 767-776.

. 2001. Beyond light: Physical, geological, and geochemical parameters as possible submerged aquatic vegetation habitat requirements. Estuaries 24: 1-17.

, J. D. Ackerman, J. Verduin, And M. Van Keulen. 2006. Fluid dynamics in seagrass ecology-from molecules to ecosystems p. 193-225. In A. W. D. Larkum, R. J. Orth and C. M. Duarte [eds.], Seagrass biology, ecology and conservation. Springer.

- AND G. Gust. 1999. Water flow in tide- and wavedominated beds of the seagrass Thalassia testudinum. Mar. Ecol. Prog. Ser. 184: 63-72.

Larkum, A. W. D., R. J. Orth, and C. M. Duarte. 2006. Seagrass biology, ecology and conservation. Springer.

Lee, K. S., And K. H. Dunton. 1999. Inorganic nitrogen acquisition in the seagrass Thalassia testudinum: Development of a whole-plant nitrogen budget. Limnol. Oceanogr. 44: 1204-1215.

Nishihara, G. N., And J. D. Ackerman. 2006. The effect of hydrodynamics on the mass transfer of dissolved inorganic carbon to the freshwater macrophyte Vallisneria americana. Limnol. Oceanogr. 51: 2734-2745.

Pedersen, M. F., And J. Borum. 1993. An annual nitrogen budget for a seagrass Zostera marina population. Mar. Ecol. Prog. Ser. 101: 169-177.

Peralta, G., F. Brun, J. L. Perez-Llorens, and T. J. Bouma. 2006. Direct effects of current velocity on the growth, morphometry and architecture of seagrasses: A case study on Zostera noltii. Mar. Ecol. Prog. Ser. 327: 135-142.

, F. G. Brun, I. Hernandez, J. J. Vergara, and J. L. Perez-Llorens. 2005. Morphometric variations as acclimation mechanisms in Zostera noltii beds. Estuar. Coast. Shelf Sci. 64: 347-356.

Peterson, C. H., R. A. Luettich, F. Micheli, and G. A. Skilleter. 2004. Attenuation of water flow inside seagrass canopies of differing structure. Mar. Ecol. Prog. Ser. 268: 81-92.

Schanz, A., AND H. Asmus. 2003. Impact of hydrodynamics on development and morphology of intertidal seagrasses in the Wadden Sea. Mar. Ecol. Prog. Ser. 261: 123-134.

Short, F. T., AND C. P. Mcroy. 1984. Nitrogen uptake by leaves and roots of the seagrass Zostera marina L. Bot. Mar. 27: 547-555.

Sintes, T., N. Marba, C. M. Duarte, and G. A. Kendrick. 2005. Nonlinear processes in seagrass colonisation explained by simple clonal growth rules. Oikos 108: 165-175.

Stapel, J., T. L. Aarts, B. H. M. Vanduynhoven, J. D. Degroot, P. H. W. Vandenhoogen, and M. A. Hemminga. 1996. Nutrient uptake by leaves and roots of the seagrass Thalassia hemprichii in the Spermonde Archipelago, Indonesia. Mar. Ecol. Prog. Ser. 134: 195-206. 
Terrados, J., AND S. L. Williams. 1997. Leaf versus root nitrogen uptake by the surfgrass Phyllospadix torreyi. Mar. Ecol. Prog. Ser. 149: 267-277.

Thomas, F. I. M., And C. D. Cornelisen. 2003. Ammonium uptake by seagrass communities: Effects of oscillatory versus unidirectional flow. Mar. Ecol. Prog. Ser. 247: 51-57.

, AND J. M. ZANDE. 2000. Effects of water velocity and canopy morphology on ammonium uptake by seagrass communities. Ecology 81: 2704-2713.
Touchette, B. W., And J. M. Burkholder. 2000. Review of nitrogen and phosphorus metabolism in seagrasses. J. Exp. Mar. Biol. Ecol. 250: 133-167.

Received: 20 November 2006 Accepted: 12 February 2008 Amended: 23 March 2008 